\title{
Association of parental FEF25-75\% during a methacholine challenge and children's PC20 and diagnosis of asthma
}

\author{
D Houlbrook ${ }^{1,2^{*}}$, AB Becker ${ }^{2}$, CD Ramsey R.4 $^{3,4}$ \\ From AllerGen NCE Inc.'s Fifth Annual Research Conference: Innovation from Cell to Society \\ Québec City, QC, Canada. 7-9 February 2010
}

\section{Background}

There is evidence that paternal and maternal lung function influence children's pulmonary function. To date, the most widely used pulmonary function test (PFT) to assess airway responsiveness is the PC20 (concentration of methacholine required to decrease FEV1 by $20 \%$ ). However, other measures of parental lung function may be better predictors of airway responsiveness or asthma development in their children.

\section{Methods}

The study population included children born in 1995 in Manitoba, who were enrolled in a nested case-control birth cohort study (Study of Asthma Genes and the Environment (SAGE). Both index children and their parents underwent PFTs and methacholine challenges to determine their PC20. Parents often had a normal PC20 but a change in flow at mid-lung volumes (forced expiratory flow at $25-75 \%$ vital capacity) was noted. Therefore, we measured parental PC30 (concentration of methacholine required to decrease FEF $25-75 \%$ by $30 \%$ ) and its association with their child's PC20 and physician diagnosed asthma. A positive PC30 was measured at a concentration of $\leq 8 \mathrm{mg} / \mathrm{ml}$. Children were assessed at age $12-13$ by a pediatric allergist for a diagnosis of asthma. Odds ratios (OR) were calculated to examine the relationship between parental PC30 and a child's PC20 and asthma. This relationship was further explored by gender.

\section{Results}

Overall 114 children and their parents were included in this analysis. Of the 114 children, 47 were females (21

'Manitoba Institute of Child Health, Canada

Full list of author information is available at the end of the article asthma) and 67 were boys (23 asthma). No significant relationship was seen between children diagnosed with asthma and having a parent with a PC30 $\leq 8$ (OR 1.07; 95\% CI 0.49-2.37) or both parents PC30 >8.

112 children [ 45 females ( 23 with PC20 $\leq 8$ ) and 67 males (46 with PC20 $\leq 8)$ ] fit the criteria for having a PC20 and participating parents. In children with a PC20 $\leq 8$ there was no relationship between having one parent with PC30 $\leq 8$ (OR 1.18; 95\% CI .54-2.63) or both parents having a $\mathrm{PC} 30>8$.

When we examined gender specific relationships, there was no association between fathers PC30 and having a son diagnosed with asthma (OR 1.32; 95\% CI 0.53.5 ) or daughters with a diagnosis of asthma (OR 1.07; 95\% CI 0.33-3.48). Similarly, there was no significant association between the father's PC30 and their child's PC20 being $\leq 8 \mathrm{mg} / \mathrm{ml}$.

In moms with a PC30 $\leq 8 \mathrm{mg} / \mathrm{ml}$ there was no association with sons that had a PC20 $\leq 8 \mathrm{mg} / \mathrm{ml}$ (OR 1.0; 95\% CI 0.51-2.0); However moms with a PC30 $\leq 8$ were significantly more likely to have a daughter with a PC20 $\leq 8$ (OR 3.56; 95\% CI 1.55-8.21). In addition, there was a significant relationship between mom's PC30 being $\leq$ 8 and a daughter having physician diagnosed asthma (OR2.34; 95\% CI 1.04-5.44). The relationship was in the same direction between maternal PC30 and a son's diagnosis of asthma, however this was not significant (OR 2.0; 95\% CI 0.99-4.05).

\section{Conclusion}

There was no relationship between children's asthma and PC20 and parental airway responsiveness measured as PC30. There was a statistically significant relationship between daughter's airway responsiveness and asthma and mothers' airway responsiveness as a PC30 FEF 25-75\%. 
Maternal mid-flow responsiveness may be helpful in identifying risk for the development of pediatric asthma. Mid lung flow changes in mothers may represent a maternal genetic influence on the development of asthma in children.

\section{Author details}

${ }^{1}$ Manitoba Institute of Child Health, Canada. ${ }^{2}$ Department of Pediatrics, University of Manitoba, Canada. ${ }^{3}$ Department of Medicine, University of

Manitoba, Canada. ${ }^{4}$ Department of Community Health Sciences, University of Manitoba, Canada.

Published: 26 November 2010

doi:10.1186/1710-1492-6-S3-P32

Cite this article as: Houlbrook et al: Association of parental FEF25-75\%

during a methacholine challenge and children's PC20 and diagnosis of asthma. Allergy, Asthma \& Clinical Immunology 2010 6(Suppl 3):P32.
Submit your next manuscript to BioMed Central and take full advantage of:

- Convenient online submission

- Thorough peer review

- No space constraints or color figure charges

- Immediate publication on acceptance

- Inclusion in PubMed, CAS, Scopus and Google Scholar

- Research which is freely available for redistribution

Submit your manuscript at www.biomedcentral.com/submit 